\title{
The spread of covid-19 and psychiatric impact on indigenous peoples
}

\author{
Tainã Brito Siebra de Oliveira' ${ }^{1}$, Jorge Lucas de Sousa Moreira' ${ }^{(D)}$, \\ Pedro Walisson Gomes Feitosa' ${ }^{1}$, Danielly Gonçalves Sombra Lima² (iD, \\ Bárbara Silveira Dionízio ${ }^{3}$ (D) Modesto Leite Rolim Neto $^{2}$ (D),
}

${ }^{1}$ School of Medicine, Federal University of Cariri (UFCA) - Barbalha, Ceará, Brazil

${ }^{2}$ School of Medicine of Juazeiro do Norte (FMJ/Estácio) - Juazeiro do Norte, Ceará, Brazil.

${ }^{3}$ School of Medicine, University of São Paulo (USP), São Paulo, SP, Brazil

\section{$凶$}

Modesto Leite Rolim Neto

School of Medicine,

Federal University of Cariri, UFCA,

Barbalha, Ceará, Brazil.

Email: modesto.neto@ufca.edu.br

Edited by

Marcelo Moraes Valença

Keywords:

COVID-19

Indigenous Peoples

Pandemic

Mental Health

\begin{abstract}
Background

Information on strategies adopted by Indigenous peoples against COVID-19 is scarce, and history shows that Indigenous peoples in the Amazon region may be particularly affected by the pandemic.

Method

The studies were identified in well-known international journals found in two electronic databases: Scopus and Embase. The data were cross-checked with information from the main international newspapers.

Results

Mental disorders in the affective spectrum (unipolar major depression, dysthymia, bipolarity) and anxiety disorders (generalized anxiety disorder, panic attacks, social phobia) also mark the reality of Indigenous psychiatric vulnerability.

Conclusions

To mitigate the impact of COVID-19 on Indigenous communities in Brazil, a health service for Indigenous groups, a crisis office, and a monitoring panel were created. In the state of Amazonas, home to more Indigenous people than any other Brazilian state, $95 \%$ of the intensive care beds are occupied. Thus, mental health disparities between Indigenous and non-Indigenous peoples may be related to the underlying economic, social, and political inequities that are legacies of colonization and oppression of Indigenous cultures; the disproportionate rates of mental disorders must be understood in context, not as intrinsic predisposition of Indigenous peoples, but as reflecting persistent inequalities.
\end{abstract}


$T^{\text {the }}$ he increase in new coronavirus cases represents a serious threat to the health of Indigenous peoples worldwide, primarily because of their precarious status of health services access. When such access is possible, there is also the need to cope with stigmatization and discrimination. ${ }^{1}$ Historically, Indigenous peoples have faced smallpox, malaria, and measles epidemics because of contact with European colonists, which culminated in irreversible genocides. However, the fear that epidemic historicity will repeat itself arises with a new biological enemy: COVID-19. ${ }^{2}$ Hence, the probable psychiatric repercussions are alarming, since Indigenous communities are at a higher risk of mental health problems, presenting psychological suffering, depression, and suicidal ideation. ${ }^{3-5}$ Psychiatric disorders such as depression, anxiety, sleep disorders, and post-traumatic stress disorder are directly or indirectly intensified by the spread of COVID-19.6

It is noteworthy that political and socioeconomic variables are related to the incidence of mental suffering among Indigenous populations. Such social segments must cope with historical traumas and the uncertainty of the present, characterized by complex phenomena of societal collapse. ${ }^{4}$ Social marginalization, racism, and loss of territories or cultural identity are risk factors for the psychological suffering of Indigenous populations. ${ }^{5}$ Native peoples in Latin America also have high social vulnerability and limited access to mental health services, especially in rural areas, both resulting from social exclusion, discrimination, and poverty processes. ${ }^{7}$ In Brazil, the highly harmful potential of COVID-19 for Indigenous Amazonian populations got attention due to the death of a Yanomami teenager. 8,9 Just a month after the first new coronavirus infection was confirmed in Manaus, Amazonas, the health system in the state collapsed. ${ }^{9}$ Conversely, the spread of COVID-19 is concomitant with the expansion of the extractive development model that exports agricultural products, in which the main vector of the virus spread is the 20,000 illegal gold miners in Indigenous Yanomami territory. ${ }^{10,11}$ Historically, the Yanomami faced epidemics caused by the influx of road builders and gold miners in the 1970s and 1980s. ${ }^{12}$

Besides Western concepts, the native definitions of mental health refer to proper levels of physical disposition and sleep levels. ${ }^{3}$ Native conceptions also see mental health as a disease that originates not only from physical aspects but also from emotional and spiritual ones, which are a byproduct of the disharmony between territory, family, environment, community, and the relationship with the elderly. ${ }^{7}$ Primary epidemiological reports analyzing 72,314 cases of
COVID-19 showed that lethality is more significant in elderly people. ${ }^{13}$ Such age-related vulnerabilities are worrisome, since the relationship with the elders of the tribes has been shown to be a factor of hope and relief from suicidal ideation, as involvement with the elderly in the tribe is linked to the strengthening of cultural identity and the reestablishment of cultural connections. This is consistent with previous research showing cultural continuity, which includes active efforts to maintain or revitalize cultural institutions and practices in Indigenous communities, as a strong protective factor against suicide in the community. ${ }^{14}$

It is essential to consider that psychiatric disorders already present in Indigenous communities, making them vulnerable populations, creates inquiries regarding processes of intensification of such realities, since the death of the Indigenous people withholds a significant part of traditional knowledge that forms an original culture. Regarding the existing realities, severe psychological distress, depression and suicidal ideation were observed in $6.2 \%, 32 \%$, and $22.9 \%$, respectively, in Brazilian Indigenous communities. ${ }^{5}$ On suicidal ideation, the study of other Indigenous populations showed that $4.9 \%$ of the Indigenous people considered committing suicide and $27.3 \%$ of those had a suicide plan; only $1.3 \%$ survived the suicide attempt. Mental disorders in the affective spectrum (unipolar major depression, dysthymia, bipolarity) and anxiety disorders (generalized anxiety disorder, panic attacks, social phobia) also mark the reality of Indigenous psychiatric vulnerability. ${ }^{3}$

To mitigate the impact of COVID-19 on Indigenous communities in Brazil, a health service for Indigenous groups, a crisis office, and a monitoring panel were created. In the state of Amazonas, home to more Indigenous people than any other Brazilian state, $95 \%$ of the intensive care beds are occupied. The epidemiological report indicates that the state has the highest incidence of the COVID-19 disease, with 19 people per 100,000 inhabitants, although the total number of cases remains a fraction of the current hotspot in São Paulo. Thus, mental health disparities between Indigenous and non-Indigenous peoples may be related to the underlying economic, social, and political inequities that are legacies of colonization and oppression of Indigenous cultures; the disproportionate rates of mental disorders must be understood in context, not as intrinsic predisposition of Indigenous peoples, but as reflecting persistent inequalities. ${ }^{15}$ Information on strategies adopted by Indigenous peoples against previous disease outbreaks is scarce, and history shows that Indigenous peoples in the Amazon region may be particularly affected by the COVID-19 pandemic. ${ }^{15}$ 


\section{Highlights}

The increase in new coronavirus cases represents a serious threat to the health of Indigenous peoples worldwide, primarily because of their precarious status of health services access.

Political and socioeconomic variables are related to the incidence of mental suffering among Indigenous populations.

It is essential to consider that psychiatric disorders already present in Indigenous communities.

Age-related vulnerabilities are worrisome, since the relationship with the elders of the tribes has been shown to be a factor of hope and relief from suicidal ideation, as involvement with the elderly in the tribe is linked to the strengthening of cultural identity and the reestablishment of cultural connections.

Severe psychological distress, depression and suicidal ideation were observed in 6.2\%, 32\%, and $22.9 \%$, respectively, in Brazilian Indigenous communities.

\section{Conflict of interest}

The authors declare that they have no competing interests.

\section{Acknowledgment}

The authors would like to thank the Suicidology Research Group from Universidade Federal do Ceará (UFC) and the Brazilian National Council for Scientific and Technological Development (CNPq) - institution linked to the Brazilian Department of Science, Technology and Scientific Writing Lab, Medicine School - Universidade Federal of Cariri (UFCA).

\section{Funding}

The Suicidology Research Group from Universidade Federal do Ceará (UFC) and Brazilian National Council for Scientific and Technological Development (CNPq) - institution linked to the Brazilian Department of Science, Technology and Innovation to encourage research in Brazil

Tainã Brito Siebra de Oliveira

https://orcid.org/0000-0002-0274-7496

Jorge Lucas de Sousa Moreira

https://orcid.org/0000-0002-9712-5058

Pedro Walisson Gomes Feitosa

https://orcid.org/0000-0003-2320-8632

Danielly Gonçalves Sombra Lima

https://orcid.org/0000-0002-2338-0734

Bárbara Silveira Dionízio

https://orcid.org/0000-0002-3568-4727

Modesto Leite Rolim Neto

https://orcid.org/0000-0001-9379-2120

\section{References}

1. COVID-19 and Indigenous peoples [Internet]. United Nations; 2020 [cited 2021]. Available from: https://www.un.org/development/desa/ indigenouspeoples/covid-19.html.

2. Reuters. Depois de varíola e malária, indígenas temem avanço do coronavírus no Brasil [Internet]. Money Times; 2020 [cited 2021]. Available from: https://www.moneytimes.com.br/depois-de-variolae-malaria-indigenas-temem-avanco-do-coronavirusno-brasil/.

3. Restrepo C, Rincón C and Urrego - Mendoza ZC. Salud mental, sufrimiento emocional, problemas y trastornos mentales de indígenas colombianos. Datos de la Encuesta Nacional de Salud Mental 2015. Rev Colomb Psiquiat 2016;45 (Suppl 1):119126 Doi:10.1016/j.rcp.2016.09.005

4. Cianconi $P$, Lesmana $C B J$, Ventriglio $A$ and Janiri L. Mental health issues among indigenous communities and the role of traditional medicine. Int J Soc Psychiatry 2019;65(4):289-299 Doi: $10.1177 / 0020764019840060$

5. Walker RJ, Campbell JA, Dawson AZ and Egede LE. Prevalence of psychological distress, depression and suicidal ideation in an indigenous population in Panamá. Soc Psychiatry Psychiatr Epidemiol 2019;54(10): $1199-1207$ Doi:10.1007/s00127019-01719-5

6. Zarghami M. Psychiatric aspects of Coronavirus (2019-nCoV) infection. 2020;14(1):e102957 Doi: 10.5812/ijpbs. 102957

7. Vélez EMM, Ríos JML, Marulanda SC, Franco MCV, Rosa ODM and Holguín DMH. Aproximación a la concepción de la salud mental para los pueblos indígenas de Colombia. Ciênc Saúde Coletiva 2020;25: $1157-1166$ Doi: 10.1590/141381232020253.17832018

8. Brazil Teen's Death Raises Virus Alert for Indigenous Groups [Internet]. The New York Times; 2020 [cited 2021]. Available from: https://www.nytimes.com/ aponline/2020/04/10/world/americas/ap-lt-virusoutbreak-brazil-indigenous.html.

9. Bertoni E. Por que o Amazonas é o $1^{\circ}$ estado a ter um colapso na saúde [Internet]. Nexo Jornal; 2020 [cited 2021]. Available from: https://www. nexojornal.com.br/expresso/2020/04/13/Porque-o-Amazonas-\%C3\%A9-o-1\%C2\%BA-estado-ater-um-colapso-na-sa\%C3\%BAde.

10. Bonilha P. Como a Covid 19 impacta os indígenas isolados? [Internet]. Greenpeace; 2020 [cited 2021]. Available from: https://www.greenpeace. org/brasil/blog/como-o-covid-19-impacta-osindigenas-isolados/.

11. Darlington $S$, Venaglia $G$ and Kaxinawa L. 
Coronavirus fears grow for Brazil's indigenous groups [Internet]. CNN; 2020 [cited 2021]. Available from: https://edition.cnn.com/2020/04/13/americas/ brazil-indigenous-coronavirus-intl/index.html.

12. First Yanomami Covid-19 death raises fears for Brazil's indigenous peoples [Internet]. The Guardian; 2020 [cited 2021]. Available from: https://www. theguardian.com/world/2020/apr/10/firstyanomami-covid-19-death-brazl-indigenous.

13. Wu Z and McGoogan JM. Characteristics of and Important Lessons From the Coronavirus Disease 2019 (COVID-19) Outbreak in China: Summary of a Report of 72314 Cases From the Chinese
Center for Disease Control and Prevention. Jama 2020;323(13):1239-1242 Doi:10.1001/ jama. 2020.2648

14. Hadjipavlou G, Varcoe C, Tu D, Dehoney J, Price $R$ and Browne AJ. "All my relations": experiences and perceptions of Indigenous patients connecting with Indigenous Elders in an inner city primary care partnership for mental health and well-being. Cmai 2018;190(20):E608-e615 Doi:10.1503/ cmaj. 171390

15. Zavaleta C. COVID-19: review Indigenous peoples' data. Nature 2020;580(7802):185 Doi:10.1038/ d41586-020-01032-1 